\title{
Ireland says No (again): the 12 June 2008 Referendum on the Lisbon Treaty ${ }^{1}$
}

\author{
BY JOHN O’BRENNAN
}

\begin{abstract}
This article analyzes the significance of the 12 June 2008 Lisbon Treaty referendum in the Republic of Ireland. This was the third such referendum on Europe held in Ireland since the millennium, and the second referendum in three to result in a rejection of an EU Treaty following the failed Nice poll in 2001. Assessing both the campaign itself and the reasons for the No vote, the article argues that whilst variables such as age, educational attainment, geography, gender and social class all have a part to play in explaining the outcome of the referendum, post-referendum analysis suggests that two key phenomena proved decisive. First, an enduring Irish attachment to an overwhelmingly exclusivist national identity rather than more open and fluid identity conceptions, means that a space exists where issues such as neutrality, sovereignty and Ireland's relative influence in the EU institutional matrix can be readily exploited by opponents of the European integration process, and where any changes in the EU constitutional order can be emotively presented as an existential threat to Ireland's values and interests. Second, post-referendum analysis also suggests that lack of knowledge constituted a key reason for voting No. The absence of any effort by government to provide and promote sufficient information channels which explain how and why Ireland's EU membership matters means that EU 'debates' within Irish political culture are frequently characterised by apathy, confusion, and ignorance, in a context where the chasm in elite-popular opinion has grown wider. The referendum result also points to a growing Eurosceptic tendency in Ireland which has seen the size of the No vote increase from 17 per cent in 1972 to a decisive majority of 53.4 per cent in 2008, on a significantly higher turnout than either 2001 or 2002.
\end{abstract}

ON 12 JUNE 2008, the Irish electorate went to the polls to vote on the adoption of the European Union's (EU) Lisbon Treaty. This was the third such referendum on Europe held in Ireland since the millennium and the second referendum in three to result in a rejection of an EU Treaty following the failed Nice poll in $2001 .^{2}$ The Lisbon Treaty was the eventual compromise agreed by EU leaders in the aftermath of the rejection of the Constitutional Treaty (CT) in popular referendums in France and the Netherlands in 2005. The Irish rejection of the Lisbon Treaty dealt an important blow 
to the constitutionalization of the EU as the Treaty represented the culmination of a defined (if somewhat messy) constitutional process: Lisbon's organic connection to the rejected Constitutional Treaty seems clear and the CT itself evolved out of a unique Constitutional Convention on the Future of Europe, instituted in February 2002 after the EU's Laeken Summit of December 2001. This article focuses on the Lisbon Treaty referendum in Ireland and analyses both the campaign itself and the reasons for the No vote. In doing so it draws upon the data presented in two key postreferendum research papers. ${ }^{3}$ The first section sets out two significant background issues which help contextualise how the campaign unfolded. The second section focuses upon the campaign itself, the coalitions which emerged for and against the treaty, the key issues raised in the course of the campaign, and the controversy generated around these issues. It also analyses the polarisation of forces which manifested itself as anti-system Euro-sceptics hostile to the Treaty against the Euroenthusiasm or Euro-pragmatism of the mainstream political parties and supporters of the Treaty. The third section analyses the results of the poll and the reasons for the No vote and seeks to locate this analysis within a broader context of Irish engagement with the European Union.

\section{Background and Context}

Before considering how the campaign unfolded in Ireland there are two important background issues which need to be examined. The evolution of the EU constitutional

order has seen member states develop their own specific instruments of legal adaptation amid a plurality of approaches to political legitimation in particularistic national contexts. In formal legal terms ratification is deemed the prerogative of each 
individual member state and it is up to each state to decide its own preferred method of constitutional approval: in the case of the Lisbon Treaty 26 of the 27 states opted for a parliamentary vote. ${ }^{4}$ In the Irish case ratification takes place through popular referendum, on foot of the decision of the Irish Supreme Court in the celebrated Crotty case of $1987 .{ }^{5}$ The dominant interpretation of that judgment was that any further change in the EU constitutional order with implications for Irish sovereignty had to be legitimated through referendum rather than parliamentary statute. No Irish government has been prepared to challenge the constitutionality of an EU treaty before the Supreme Court since that time and no such action was contemplated in respect of the Lisbon Treaty. This is despite the fact that Crotty expressly authorises the ratification of EU treaties by statute provided that 'such amendments do not alter the essential scope or objectives' of the existing European Union. ${ }^{6}$ The only aspect of the Single European Act (SEA) that the Court felt required constitutional amendment - and this only by a 3 to 2 majority - was Title III, which pertained to European security and foreign policy. It is absolutely clear that all other institutional and procedural innovations contained in the Single European Act could as easily have been introduced by statute of the Oireachtas. Indeed, as Ruth Barrington points out, successive enlargements of the EU have been ratified by the Oireachtas rather than by referendum, and it is at least arguable that these have altered the essential scope and/or objectives of the EU far more than actual treaty change. ${ }^{7}$ Viewed from this perspective the government would have been perfectly justified in incorporating the very modest institutional changes attached to the Lisbon Treaty into Irish law by statute rather than constitutional amendment. Given that the Lisbon Treaty contained only limited movement towards further 'deepening' of foreign and security policy, and leaves intact each member state's absolute sovereignty in foreign affairs, it might 
have seemed to some as inherently sensible for the government to opt for parliamentary ratification or at least to test the constitutionality of the Lisbon Treaty before the Supreme Court in advance of or in preference to the much more risky route of a popular referendum.

The government's decision to proceed cautiously and avoid a confrontation with the Supreme Court was based on a strategic recognition that if the action failed it would have been presented by the No side as a deliberate effort to exclude the Irish people from the decision-making process and thus prove a significant weapon in the antiintegrationist armoury in the course of a referendum campaign. The impression of a so-called 'Euroelite' going over the heads of the people, already popularly embedded, would no doubt be reinforced by such a turn of events. Thus for the Irish government calling a referendum represented the only sensible response to the Supreme Court decision which, in the opinion of one leading constitutional law expert, should have long ago been overruled or modified by the court itself. ${ }^{8}$

A second key background issue was the change of Taoiseach. Bertie Ahern's private life become more and more the defining issue of Irish politics subsequent to the general election of 2007 won by a Fianna Fáil-led coalition and he had to suffer the indignity of being dragged before a public tribunal of inquiry - the Mahon Tribunal to explain how and why huge sums of money had been provided to him by businessmen on numerous occasions over a decade previously. Obsessed with the Tribunal, Ahern failed to concentrate on Lisbon early enough and dithered about naming the date, leaving a vacuum for the No camp to exploit. Opposition leaders complained vocally about the impact the delay was having on the Yes campaign. 
Ahern finally announced his resignation on 2 April 2008 and thus the way was clear for finance minister, Brian Cowen, to assume the mantle of leadership of Fianna Fáil and Taoiseach. Political scientists will mull over the Ahern affect: was there an instrumental counter-plebiscitary effect arising out of the revelations about Bertie Ahern's finances? Or was there a wider disaffection with party politics and distrust of political elites which resulted in the rejection of a position advocated by $90 \%$ of the members of parliament? At the very least the atmosphere of turbulence and semipermanent political crisis helped to distract attention from the substantive question at a crucial juncture.

The Campaign: pro- and anti- Treaty coalitions and key issues

From the outset of the campaign a clear polarization between Yes and No sides manifested itself as one of 'political establishment' insiders versus non-political or politically marginal outsiders, a not wholly new feature of Ireland's European debate but arguably one of growing importance. Michael Holmes points out that the huge majority enjoyed by the Yes side in the original accession referendum in 1972 (83\%) helped create a culture of complacency among Irish elites about referendum outcomes. This was reinforced by distance from the legislative process - only a small number of ministers and civil servants in Dublin and Brussels have had any substantive input into policy over the years. The extraordinary consensus amongst the political parties on EU membership combined with the vagaries of a political culture which has remained resolutely localist and clientelistic also helped insulate decisionmaking on Europe from elected representatives as much as ordinary citizens. ${ }^{9}$ Over time this culture of official neglect and ignorance helped create opportunity structures 
for smaller and politically marginal groups to effectively dominate the antiintegrationist agenda and mobilise constituencies which felt largely ignored by the Europhile political parties.

On the Yes side stood the Republic’s dominant political party, Fianna Fáil, as well as the two largest opposition parties, Fine Gael and Labour, and Fianna Fáil’s small coalition partner, the Progressive Democrats. ${ }^{10}$ The second party in the governing coalition, the Green Party, which had campaigned against previous EU treaties, and especially forcefully against the Nice Treaty in 2001 and 2002, did not take an explicit party position but its ministers performed a volte face and expressed unequivocal support for the Treaty. Other traditional supporters of the EU were also on board: the Irish Business and Employers Federation (IBEC), the Irish Chambers of Commerce, the Irish Congress of Trades Unions (ICTU), and a broad-ranging group called the Irish Alliance for Europe, a non-party, civil society umbrella group comprising academics, businesspeople, farmers, lawyers, students, and trade unionists. On the No side many of the party political actors were familiar from previous referendums on EU issues. Sinn Féin has been actively opposed to European integration since the 1972 referendum (though it professes itself to be a pro-European party). The second active political party was the Socialist Party which emerged out of the militant wing of the Labour party in the late 1980s but which lost its only Dáil seat in 2007. The Socialist Workers Party and the Communist Party of Ireland also campaigned against the Treaty, whilst independent Eurosceptic politicians such as MEP Kathy Sinnott and former MEP Dana Rosemary Scallon gave added voice to the opposition campaign. 
The most visible and organizationally competent components of the No campaign, however, were not established political parties but rather activist groups and movements adhering either to a single issue objective, or, in a minority of cases, professing a broader critique of the European integration process. We can divide these groups into four distinct categories. The first such group coalesced around the desire to protect Irish sovereignty and identity against the alleged ambitions of the EU to both fully federate and militarise itself. The oldest of these groups is Anthony Coughlan's National Platform which has been campaigning against European integration since the early 1970s when it was known as the Irish Sovereignty Movement (ISM). ${ }^{11}$ A second category of groups in this oppositionist strand is more explicitly concerned with developments in European foreign and security policy. The Peace and Neutrality Alliance (PANA), for example, campaigned against a 'European Army' and the European Defence Agency, whilst other group such as AfrI focus on development issues and Third World politics and the alleged imperialist biases and ambitions of the EU toward Africa in particular. At first glance it is not particularly obvious what unites these groups but concerns about neutrality, American aggression and hegemonic ambition, and EU militarisation featured strongly during the campaign. A second strand of the left opposition to Lisbon can be found amongst groups formed around welfare issues and social policy. As Michael Holmes demonstrates the left-wing critique has been a permanent feature of Irish opposition to European integration and concentrated outside of parliament (where there was virtually no voice) in interest groups. ${ }^{12}$ These groups include the People's Movement and the People before Profit Alliance, which both emphasised strongly their view that the Lisbon Treaty constituted a vehicle for the privatization of public services. Other core concerns voiced amongst these groups included the alleged neoliberal bent of the 
European Commission and the unelected 'Brussels Bureaucracy', the supposed 'race to the bottom' provoked by inter-state competition within the EU Single Market, and, at the individual level, by labour mobility (the Polish Plumber familiar from the 2005 French referendum).

If such left wing critiques are familiar from other jurisdictions there has also developed a distinct right wing Irish economic critique of the EU and on this occasion it was led spiritedly by a new group called Libertas. Led by Tuam-based multimillionaire businessman Declan Ganley, a newcomer to frontline politics and with connections to American defence and security interests, Libertas placed the alleged threat to Ireland's laissez faire corporate tax regime at the centre of its campaign. And whilst it also invoked arguments about sovereignty, institutional power and Irish identity, its unique contribution to the campaign lay in its emphasis on the EU as an economic threat to Irish competitiveness, as something which no longer constituted an unvarnished public good from an Irish perspective. For the first time in an Irish referendum a significant number of prominent business people also publicly opposed the Treaty, though it is not clear that their opposition was based on any specific set of economic arguments. These included Ulick McEvaddy, Ben Dunne and the colourful Ryanair chief executive, Michael O’ Leary. Finally, on the conservative social right, the campaign featured a number of prominent ultra-Catholic groups led by Cóir which had been active over the previous decade or more. Opposed to abortion, divorce and homosexuality, and arguing that the Lisbon Treaty would also encourage the growth of euthanasia and prostitution, Cóir's particular focus during the campaign was the Charter of Fundamental Rights, which they alleged would be used as a Trojan horse to introduce extreme secular legislation which would further erode Irish identity and 
attachment to Christianity. And although Cóir too utilised arguments about institutional power, the democratic deficit and sovereignty, its main emphasis was on conservative social values.

So if these were the main actors active during the campaign what where the key issues which framed the debate? For the purposes of clarity and simplicity we can delineate along two clearly identifiable vectors. First, arguments about sovereignty and identity presented Lisbon either as a threat to or an enhancement of Ireland's power and influence within the European Union and beyond. The second set of issues concerned the economy and the extent to which the Lisbon Treaty constituted a beneficial or negative change to Ireland's economic position within the EU. In one form or another these two vectors have dominated Ireland's seven referendums to date on EU issues.

Turning first to the sovereignty and identity vector, one can identify two significant dimensions of the No campaign that presented Lisbon as an existential threat to Irish identity and national interests. The first was the institutional re-calibration which included changes to the structure of the Commission and the modus operandi of the Council of Ministers. Essentially these arguments were about Ireland's voice and institutional representation in Brussels and the changes wrought by the Lisbon Treaty relative to the status quo. But they also included the nature of large state-small state relationships within the EU, the alleged 'democratic deficit' which the EU was said to suffer, the concept of citizenship in a national and European context and the nexus between Irish identity and European integration. The second element was the spectre of militarisation and the alleged development of a European Army as both undesirable of itself and as a threat to Irish neutrality, sovereignty and identity. Both arguments 
were familiar from previous referendum campaigns. ${ }^{13}$ Both proved effective in mobilising No voters.

The No side argued that the legitimacy of the EU depended on full and equal representation of all member states in the decision-making structures. The right of each state to a seat at the Commission table at all times was thus sacrosanct. Indeed the commitment to one commissioner per member state was a key principle of Ireland's European policy until Nice. The loss of a commissioner for one term in three, effectively five years out of every fifteen, was presented by the No side as a significant further diminution of sovereignty and influence for Ireland with no compensating 'side payments' offered within the broader institutional matrix. Sinn Féin was particularly insistent that rejection of Lisbon would mean re-negotiation and the opportunity to keep a commissioner permanently. Their position can be summed up in Padraig MacLochlainn’s view: ‘For a small country like Ireland, it is vital to have a permanent voice at the European Commission table, especially when you consider that this country only has a small number of MEPs and our voting strength in the Council of Ministers will be halved if this is passed'. ${ }^{14}$ What Sinn Féin and others on the No side failed to point out was that Ireland, under the terms of the existing Nice Treaty, would potentially lose a commissioner as early as 2009. Under Lisbon that would not happen until 2014 at the earliest, and there existed the potential to retain commissioners under Lisbon if all member states so agree. Indeed the Irish Government, as part of its strategy for preparing a second referendum in 2009, was later able to secure agreement at the December 2008 European Council summit that each member would retain a permanent place at the Commission table. ${ }^{15}$ Bizarrely, as is illustrated by the discourse of both Sinn Féin and the National Platform, the very 
actors who were now stressing the imperative of maintaining a permanent Irish commissioner had long presented the Commission as an über-centralising force of unelected, power-obsessed bureaucrats intent on reducing Irish national sovereignty as they accumulated more and more power. Public opinion analysed both during and after the campaign, demonstrated a strong attachment to the idea of a permanent Irish commissioner and in this sense the No argument was certainly a very persuasive one. At the very least it contributed to the agreement on a 'one commissioner per member state’ rubric agreed at the December European Council.

The second strand of the institutional power debate focused on changes to the voting weights in the Council of Ministers, the EU's primary law-making body. The National Platform asserted that the Lisbon Treaty effectively doubled Germany’s weight within the Council from its present $8.5 \%$ to $17 \%$. Similarly France and the UK would see their voting weight increased from their present $8 \%$ to $12 \%$ in a context where Ireland's voting power would reduce from $2 \%$ to $0.8 \%$. In combating these claims, supporters of the Treaty stressed that the changes in Quality Majority Voting (QMV) did not necessarily present a threat to Irish interests. In the consensus-seeking environment of Brussels the veto was little more than a mythical realpolitik construct: the consensual nature of EU decision-making processes is such that the zero sum calculations of the No side do not equate with reality. As Brigid Laffan pointed out: 'the hard evidence is that the EU system remains largely driven by consensus. Only $25 \%$ of decisions that could have gone to a vote between $1994-2004$ were voted on' ${ }^{16}$ Thus clashes about institutional power and Ireland's voice in Brussels became an important part of the debate on the Lisbon Treaty as the campaign wore on. To the 
extent that they resonated with concerns about Irish identity, influence and sovereignty they would play an important part in the outcome of the referendum.

The issue of an emerging European defence and security policy has featured strongly in Ireland's European debates since at least the Maastricht Treaty and was a significant concern among voters in the 2001 and 2002 Nice polls. ${ }^{17}$ A number of political parties, including Sinn Féin, along with a range of civil society groups such as PANA, coalesced around this theme and argued that Irish neutrality had been steadily eroded by successive treaties, and would be further compromised by Lisbon. In effect the No side sought to paint a picture of untrammelled 'movement' in the area of defence and security policy; the Government could not be trusted to protect neutrality and indeed was suspected of colluding with other EU member states in the 'creeping militarisation' of the EU. Those making the militarisation argument continually sought to link the EU to a militarist agenda ${ }^{18}$ and, despite all the evidence to the contrary, specifically to an American militarisation agenda. The Irish government's decision to allow the US military to stop-over at Shannon airport from the outset of the Iraq War - itself not a decision but simply the continuation of a longstanding agreement - was depicted as the thin end of the wedge, with a progressive movement toward a maximailst defence and security agenda. The No side made particularly effective use of the Lisbon Treaty’s incorporation of a European Defence Agency (EDA) 'the function of which is to expand and improve EU military expenditure' according to PANA's Roger Cole and 'will mean more arms exports and a boost to the global arms trade' ${ }^{19}$ Thus the No side's argument can be summed up as Lisbon not just enhancing EU security and defence capacity but indicative of a move toward centralization of military power and a more unified and aggressive (pro- 
American) EU posture in global politics. Yes campaigners struggled to convince voters that Ireland's veto on foreign and security policy remained and that Lisbon constituted no threat to Irish sovereignty and institutional autonomy. The postreferendum findings presented by Millward Brown IMS demonstrate the extent to which the No arguments resonated with voters: fear of conscription into a putative 'European army' featured strongly in the reasons given by No voters for their rejection of the Treaty. ${ }^{20}$

From the beginning of the campaign issues related to Ireland's place within the European and global economy featured strongly. Arguments revolved around the balance between capital and labour within a European integration context and the significance of the Lisbon Treaty for Ireland's economic autonomy and international competitiveness. The curious nature of this conversation, much of it familiar from the French referendum of 2005, lay in the EU being interpreted in precisely the opposite terms according to the actor involved, the argument being advanced and the ideology underpinning the argument. The protection of Ireland's corporate tax regime assumed a central place in the campaign of those on the right of the political spectrum such as Cóir and Libertas (but also curiously Sinn Féin, which styles itself as a socialist party) who were particularly eager to stress the competitive threat facing Ireland if Lisbon were to be ratified, with Libertas leader Declan Ganley claiming: 'Ireland's tax competitiveness is absolutely put into a very tenuous position'. Asserting that the mainstream political parties could not be trusted on the tax issue, Ganley argued that Ireland's strategy should be to seek something stronger than the veto, namely a legally binding protocol which would guarantee absolute independence to set national tax policy and especially Ireland's low rate of corporate tax. ${ }^{21}$ It was frequently asserted 
that a large number of EU states, but particularly France as the incoming President of the EU, would push for a Common Consolidated Corporate Tax Base (CCCTB) on the basis of enhanced cooperation procedures which would effectively circumvent an Irish veto on corporate tax. With fiscal autonomy constrained by Ireland's membership of the Eurozone tax policy was presented as the key contemporary instrument of sovereign economic power. In an economy plunging into recession, and with the Celtic Tiger era now a distant memory, these arguments received a serious hearing. $^{22}$

In marked contrast the left critique of the European integration process focused on the alleged neoliberal bias of the European Union and the ongoing attacks on 'Social Europe' by the European Commission, corporate Europe and the European Court of Justice (ECJ) whose policy agenda invariably produces negative distributional asymmetries in Ireland. But whereas in France in 2005 social and economic issues dominated the campaign and arguments about EU market failure penetrated thoroughly through different sections of society, in Ireland this remained difficult for the Left. After all the Irish social model is a much more minimalist one than the French and so there is much less to 'defend' than in France when arguing against EU competition policy or open markets. Nevertheless for a good part of the left opposition to Lisbon, resistance to the rampantly neo-liberal ideology of 'Brussels', said to become even more entrenched with new articles in the Lisbon Treaty, was a key element in the propaganda battle with the spectre of Commission-led globalisation presented as an existential threat to the interests and welfare of Irish workers. A particular target of attack was the ECJ, which despite its record of robust interventionism on the side of workers rights, was routinely presented as a friend of 
the market rather than the worker: 'the court's decisions are sustained attacks on the wages and working conditions of workers throughout the EU' according to Roger Cole of PANA. ${ }^{23}$ The ECJ was continually interpreting the treaties in a way which favoured ‘competition’ over labour and local collective bargaining arrangements. In particular the Laval and Viking judgments featured strongly in No arguments, as ‘evidence’ of ECJ perfidy.

The outcome: Ireland votes no (again)

It became apparent early in the count that a No vote was the certain outcome of the referendum. On a turnout of $53.13 \%$ the proposed constitutional amendment was defeated by $53.4 \%$ to $46.6 \%$. The outcome was almost exactly that predicted by the Irish Times/TNSmrbi poll one week before polling. ${ }^{24}$ A total of $28.3 \%$ of the electorate voted No - compared with $24.7 \%$ of the electorate who voted Yes. This constituted a historical peak for the No side which, even in victory in 2001, had only garnered the support of $19 \%$ of the electorate. The margin of defeat, as Table 1 shows, was 110,000 out of an overall turnout of over 1.6 million people. ${ }^{25}$

So what factors explain the outcome? Within days of the referendum the European Commission conducted an extensive survey of public opinion providing important data on voting behaviour. ${ }^{26}$ The first striking behavioural aspect of the outcome was the turnout. Prior to Lisbon most commentators expected that the higher the turnout the more likely it was that the Yes side would prevail. In 2002, for example, a marked increase in turnout compared to the 2001 poll (see Table 1) enabled the Yes side to 
improve its vote enough to command a clear victory. But the Lisbon referendum, although producing a significantly higher turnout level than 2001or 2002, did not see this pattern repeated as most additional voters seem to have voted against the Treaty. The turnout figure (55.13\%), while it compares poorly to the French referendum of 2005 (69.3\%), and to, for example, Danish referendums on EU issues, nevertheless was sufficiently healthy in an Irish plebiscitary context as to bestow added legitimacy to the result.

Analysis of actual voting behaviour reveals some interesting comparative trends. Only 10 of the 43 constituencies in the state voted in favour, in some cases by a slim majority. Whilst this was significantly better than 2001, when only 2 constituencies voted Yes and 39 against the Nice Treaty, it is strikingly different to 2002 when all 42 constituencies recorded Yes majority votes. If nothing else these figures demonstrate the extreme volatility of constituency results across the three most recent referendums. The extent of the success of the No campaign's arguments can be gleaned not just in the result of the referendum, but from the data presented in the post-referendum Eurobarometer survey and the Millward Brown IMS research. It showed that a large majority of Irish voters (68\%) said the No campaign was the more convincing one, while only $15 \%$ said the same about the Yes campaign. Strikingly, even those who voted Yes were more likely to say that the No campaign was more persuasive (57\% - compared to $29 \%$ who thought the Yes campaign was the more convincing one).

Turning to a more sociological approach to the profile of Yes and No voters a number of issues arise. The first is the rural-urban divide. The constituencies which voted for 
the Treaty were mostly in Leinster in the more densely populated east of the country close to Dublin. The sole constituency outside Leinster which voted Yes was Clare in the Midwest of the country. This suggests that a distinct rural-urban divide may now be a feature of Irish voting patterns on Europe, although some working class areas of Dublin also voted No. It is worth noting that in France in 2005 there was a similar large rural No vote in evidence. This was particularly pronounced among the French farmers who, like their Irish counterparts, have benefited disproportionately from the Common Agriculture Policy (CAP) over the years and yet seem less than reconciled to the European integration process. ${ }^{27}$ The strongest Yes vote, in the country was, unsurprisingly, recorded in affluent Dun Laoighaire in south east Dublin with a 63.5\% Yes vote, the strength of which highlights the significant occupational polarization in voting patterns - attitudes to the EU derived from social status are quite striking in Ireland as elsewhere. One important manifestation of this cleavage can be evinced in turnout figures: while $57 \%$ of white collar workers voted only $48 \%$ of blue collar workers did so. ${ }^{28}$ There was considerable support for the Treaty among the liberal professional and executive classes, and educational attainment influencing subjective assessment of knowledge of the treaty proved a strong indicator of support for the Treaty. In fact during the campaign there was a 25 point gap between levels of subjectively assessed knowledge as between those in upper middle and middle class occupations and those in working class occupations. ${ }^{29}$ The Eurobarometer survey demonstrates that the main supporters of the Treaty were indeed to be found in the higher occupational classes: senior managers (66\%), the 'self-employed' (60\%), professionals (58\%), and those with higher levels of education (57\%). ${ }^{30}$ On the other hand blue collar voters were largely supportive of the No vote, especially those members of trade unions such as UNITE and the TEEU which urged their members to 
vote No. Richard Sinnott argues that the social class cleavage may well constitute 'a reflection of occupation-related differences in exposure to a vulnerability in the face of globalisation'. At the very least the combination of occupational difference plus the urban-rural divide produce 'considerable socio-demographic contrasts in support/opposition to the treaty' ${ }^{31}$

The Eurobarometer survey also demonstrates that a higher proportion of younger people voted against the Treaty: among the $18-24$ group fully $65 \%$ voted No, as against only 55\% of over 55s. There is a direct link here to the question of knowledge of EU affairs in that there was a 13 point gap in levels of good/some knowledge between those under 25 and those aged 50 to 64 . Turnout level was strongly related to age: of those who did not vote in the referendum, younger people were much less likely to participate than their older counterparts $(64 \%$ of the $18-24$ year-olds abstained compared to less than one third of the 55 plus age group). ${ }^{32}$ In France in 2005 age also was clearly a factor with older and retired people much more likely to support the Constitution than younger people. ${ }^{33}$ Gender also appears to have been a somewhat influential variable. Lack of confidence in one's knowledge was more prevalent amongst women, particularly amongst younger women - the gap between males and females among the under 25s was 16 percentage points, compared with 5 points in the 50 to 64 group. ${ }^{34}$ The Eurobarometer survey demonstrated that women were firmly in the No camp with 56\% voting against the Treaty compared to 51\% of men. $^{35}$

If this data provides valuable information about electoral behaviour there are two substantive issues which help us to contextualise that behaviour. The first is the way 
in which Irish conceptions of identity may have influenced voters' perceptions of the Lisbon Treaty and Ireland's place in the integration process. The second is the question of knowledge. Richard Sinnott's post-Lisbon analysis suggests a particular context in which identity matters in the Irish context. Voters testified that a major reason for voting No was to 'keep Ireland's power and identity'. Sinnott points out that Eurobarometer surveys reveal a distinct attachment amongst Irish respondents to an 'Irish only' identity over more open and cosmopolitan identity attachments. Fully 59\% of Irish respondents in 2008 rejected the proffered degrees of European identity and opted for an exclusive Irish identity, an increase from $49 \%$ in the Eurobarometer survey of autumn 2003. In fact amongst the EU27 only UK respondents exhibit a stronger attachment to an exclusivist conception of identity. ${ }^{36}$ John Coakley argues that notwithstanding the strong currents of support for European integration, Ireland's enduring attachment to nationalist values should not be under-estimated: 'a history of vigorous nationalist agitation, a tradition of suspecting powerful neighbours and a long-standing emphasis on national sovereignty have been outstandingly characteristic of Irish political culture'. ${ }^{37}$ Sinnott's conclusion, a qualified one, is that 'running an integrationist referendum in a political culture in which almost two thirds of the electorate feel themselves to belong exclusively to a certain national identity is never going to be a walkover' ${ }^{38}$ Fully $12 \%$ of respondents to the Eurobarometer survey voted No to 'protect Irish identity' (the second most important reason for voting No) suggesting that the identity dimension emerges as crucial in explaining the outcome of the referendum. At the very least this suggests that the undoubted material gains accrued by Ireland from participation in the European integration process. ${ }^{39}$ have not contributed to any meaningful re-calibration of Irish identity conceptions and that the 'European' layer of Irish identity is in reality so thin that the consistently high 
professions of support for the EU in opinion polls may now be considered highly suspect. Where that support has been tested at the ballot box, two out of the last three popular votes have produced anti-integrationist outcomes.

The second substantive issue with a bearing on the outcome concerns voters' knowledge about the Treaty and the EU more generally. Unlike elections, referendums focus on a single issue about which voters may or may not have adequate information or pre-existing opinions. A considerable body of data accumulated during previous referendums and from Eurobarometer tracking polls demonstrates that although the Irish remain amongst the most enthusiastic about EU membership, there remains a significant knowledge vacuum, with a large majority of citizens professing to know little or nothing about how decisions are made at EU level and how the EU institutions function. The failure of the 2001 Nice referendum may have sent shockwaves through the Irish body politic but it did not encourage any significant widening of the European conversation nor any government-sponsored campaign of civic education that may have helped break through the walls of ignorance. The Lisbon campaign then in some ways manifested a sense of 'political Groundhog Day' in that the lessons which should have been absorbed in 2001 clearly were not, with the result that Irish citizens were no better informed about the issues at stake at the beginning of the Lisbon campaign than they were at the outset of the Nice campaign in 2001. Eurobarometer polls consistently demonstrate that support for the EU is related to relative levels of knowledge. The post-referendum Eurobarometer survey confirmed that once again lack of knowledge constituted the most important reason for not voting (22\%). Further data support this statistic: fully one fifth of No voters and one sixth of Yes voters did not know if the Lisbon Treaty would be good or bad 
for Ireland. ${ }^{40}$ The evidence from the Millward Brown IMS research is even more striking: of those who abstained $46 \%$ cited lack of knowledge or information as their main reason for not voting, whilst, crucially, $42 \%$ of those who voted No also cited lack of knowledge and/or information. ${ }^{41}$

The significance of the knowledge vacuum is particularly evident in the strategies adopted by the No side in particular. Two specific approaches can be identified. First, the No campaign centred on short, sharp messages easily understood, which provided voters with easy to process (negative) images of the EU and the Lisbon Treaty, in contrast to the Yes messages which invariably came across as complex if not tortured (the EU as an abstract and variegated public good). Second, the No side demonstrated an ability and willingness to distort and misrepresent both the content of the Lisbon Treaty (especially institutional changes, tax arrangements and security and defence issues) and the nature of the European integration process. These arguments could only succeed in a political space characterised by confusion, ignorance and apathy on the part of an electorate lacking any substantive connection to or sense of ownership over the EU's decision-making processes. That these arguments did succeed is confirmed by the findings of the post-referendum opinion polls: when voters were asked to identify what was in the Lisbon Treaty 65\% identified 'loss of a commissioner'; 42\% endorsed the view that Lisbon 'eroded Irish neutrality; 43\% thought that Lisbon meant the 'end of Ireland's right to decide its own corporate tax rate'; 34\% thought Lisbon would mean an 'end to control over abortion' and 33\% thought the Treaty 'would introduce conscription to a European army'. ${ }^{4}$ 
Turning finally to the party political arena there appears to have been significant divergence from party positions among party members. ${ }^{43}$ Table 2 shows the relationship between party identification and referendum in the three most recent EUrelated polls. Putting the Lisbon referendum under the party identification microscope it is clear that voters did not take their cures from the parties and political representatives they supported as recently as the 2007 general election. Party loyalty did not persuade voters to back the Yes campaign: only 60\% of Fianna Fáil supporters voted Yes and just 51\% of Fine Gael supporters voted in favour of the Treaty, whilst a majority of Labour and Green party supporters voted against. Most significant here are the $40 \%$ of Fianna Fáil supporters who voted against Lisbon as they constituted the single largest component of the No vote. Given that historically Fine Gael has been the party with the strongest support for the European integration process the latter figure appears particularly illuminating. Even in Fine Gael Leader Enda Kenny's constituency of Mayo, the Treaty was rejected by a solid margin of $61.7 \%$ to 38.3\%. Clearly, except in the case of small parties Sinn Féin and the Progressive Democrats party loyalty was not a significant indicator of voting behaviour. It is also worth comparing the voting behaviour of Irish party members with those of French political parties in the 2005 referendum in France. Using exit polls Vivaldi demonstrates that UMP and UDF supporters voted massively in favour of the European Constitution with 80 and 76\% of Yes votes respectively, a marked contrast with the voting behaviour of supporters of the three main Irish political parties in 2008. ${ }^{44}$ Midway through the campaign then-Libertas executive director Naoise Nunn asserted that the group's strategy was based around targeting 'people in the mainstream parties who have their doubts'. ${ }^{45}$ The evidence suggests that this strategy proved highly successful. Undoubtedly also divisions and bickering amongst the main 
parties did not help the Yes case. Taoiseach Brian Cowen accused Fine Gael and Labour of not doing enough to make the case for Lisbon. ${ }^{46}$ In return Fine Gael charged that Fianna Fáil had mobilized far later than them and far too late to be effective.

The lack of conviction and lacklustre mobilisation efforts of the three largest parties tell us something about Irish elites' approach to and understanding of EU membership. There is no evidence of any real internalization of 'Europe': membership has been perceived in consequentalist and utilitarian (the economic benefits reaped) rather than in normative terms (membership as a good in and of itself). The enduring localism of Irish party politics means that only a very small number of Irish parliamentarians exhibit any interest in European affairs despite the ongoing 'Europeanization' of more and more areas of domestic policy. It is this lack of engagement with and isolation from 'Europe' that perhaps best explains the gap between party members and elites in respect of recent EU referendums: increasing numbers of otherwise loyal party members simply do not take seriously the pleas to vote for something which their party elites seem less than reconciled to or enthusiastic about.

\section{Conclusion}

The rejection of the Lisbon Treaty plunged Ireland into a profound political crisis, not least because EU leaders indicated an unwillingness to re-negotiate any part of the Treaty: it would be up to Ireland to find an Irish solution to this European problem. Coinciding with this impasse in Irish-EU relations an economic recession began to 
present serious difficulties as the public finances deteriorated to their worst state in 25 years thus presenting Brian Cowen's government with the most challenging set of circumstances in which to think about moving forward. ${ }^{47}$ The Irish rejection of Lisbon also led directly to ratification problems in other member states as procedures were set in motion by Euro-sceptic actors in the Czech Republic, Poland and other states to legally challenge domestic ratification processes.

The outcome of the referendum may seem paradoxical to some in that Eurobarometer opinion polls of attitudes to the EU continue to demonstrate that Irish people are strong supporters of the integration process. The problem is that these favourable attitudes vary considerably in intensity. It seems clear from the post-referendum data that the pro-European side manifestly failed to provide voters with either normative or utilitarian reasons to endorse the Treaty. The 'soft bloc' of support for European integration crumbled in the face of a vigorous No campaign and a lack of confidence among citizens in their ability to understand both the content of the Lisbon Treaty and the nature of EU decision-making processes. It may be that even if the referendum fits easily into a first -order rather than a second-order image of European politics (in that European rather than national or local issues predominated) there were elements of the second-order paradigm in evidence. The sense of 'expressive' or 'insincere' voting, defined as voters' choosing to vote with their hearts rather than minds, is one manifestation of this. Certainly, the relatively low turnout level (significantly below the general election of 2007) could be viewed as a classic symptom of a second-order political event and one lacking salience to the public. 
Irrespective of this the referendum result was clearly influenced by a double disconnect - between political elites and voters on the one hand, and between party leaderships and party members on the other. It is difficult to tell whether the result indicates the rise of an anti-Establishment politics among the public and the rise of anti-system forces on the margins of the political system. On the face of it the success of these non-party political actors suggests a new type of politics emerging in Ireland. But the result of the 2007 General Election in the Republic would indicate a pretty stable and unchanging political order where Fianna Fáil and Fine Gael continue to dominate. It is worth remembering that many of the leading exponents of a No vote in the Lisbon referendum stood unsuccessfully for election in 2007, despite enjoying high profiles in national politics and the opportunities offered by the Irish proportional representation system. These included Richard Boyd Barrett of the People Before Profit Alliance, Richard Greene of Cóir, Joe Higgins of the Socialist Party, and Mary Lou MacDonald of Sinn Féin.

Whilst the article argued that variables such as age, educational attainment, geography, gender and social class all have a part to play in explaining the outcome of the referendum, post-referendum analysis suggests that two key phenomena proved decisive. The Irish attachment to an overwhelmingly exclusivist national identity rather than a more open and fluid (including ‘European’) identity means that a space exists where issues such as neutrality, sovereignty and Ireland's relative influence in the EU institutional matrix can be readily exploited by opponents of the European integration process and where any changes in the EU constitutional order can be emotively presented as an existential threat to Ireland's values and interests. The absence of any effort by government to provide and promote a civic education 
programme or sufficient information channels which explain how and why Ireland's EU membership matters means that EU 'debates' within Irish political culture are frequently characterised by apathy, confusion, and ignorance, with an increasingly wide chasm in elite-popular opinion. Thus 'lack of knowledge and information' emerge as a key variable is explaining voting behaviour.

There are now real grounds to argue that the Irish No to Lisbon represents the culmination of a discernible and growing Eurosceptic voting trend in the Republic of Ireland. After all, opposition to the integration project, tracked through the $7 \mathrm{EU}$ related referendums held since 1972, demonstrates an increase in the No vote from 17\% in 1972 to 30\% in 1987 (Single European Act), to 31\% in 1992 (Treaty on European Union), to 38\% in 1998 (Amsterdam Treaty), a winning majority in the Nice referendum of 2001, partly reversed in the second Nice referendum of 2002, but culminating in a decisive majority of $53.4 \%$ in 2008 , on a significantly higher turnout than either 2001 or 2002. Whereas the No vote was secured with virtually the same percentage of the vote in both 2001 and 2008 (54\%), this translates into 529,478 votes in 2001 rising to a much larger bloc of support $(862,415)$ in 2008. Such a substantial increase in real people voting against an EU Treaty cannot be dismissed as an aberration or a statistical outlier attributable to a poor Yes campaign, the 'stickiness' of Irish identity constructions, or lack of knowledge on the part of citizens, though these certainly played their part in the defeat of the Lisbon referendum. Rather it points to a solidification of and advance by an increasingly assertive and vocal antiEuropean bloc in Ireland which combines tactical astuteness with increasing financial backing and organizational sophistication. Whilst most of the major figures within this Euro-sceptic movement are located outside of the Oireachtas (and thus outside of 
mainstream political structures) it is clear that the arguments they expound resonate with more and more Irish citizens.

In this sense the rejection of the Nice Treaty in 2001 can be viewed as a watershed in Ireland's relationship with the European Union. What it signalled was not just the end of the era of 'permissive consensus' on EU issues, but that in the absence of substantive welfare-enhancing measures which can be effectively communicated to citizens, the EU space in Ireland is one where the pro-integration side finds it increasingly difficult to persuade voters to match the overwhelming support for Ireland's EU membership with active consent for changes to the EU constitutional order and policy agenda. Irish citizens and even committed political party members are now quite prepared to disregard party loyalty when confronted with EU referendums. An increasingly confrontational (largely British-based) Euro-hostile media fan the flames of anti-integration sentiment at every opportunity and provide a valuable platform for the Euro-sceptic lobby to disseminate their views. ${ }^{48}$ The tentative measures introduced by the government after 2001 such as the institution of a National Forum on Europe clearly have not succeeded in bridging the gap between the largely pro-European elites and the mass of Irish citizens: 'communicating Europe' has become a thankless and unwelcome (if indeed fitfully periodic) task for mainstream political representatives rooted in a robustly localist political culture and who themselves have both little opportunity to influence EU policy-making and little to gain from engaging seriously with EU affairs. ${ }^{49}$ To add to this the unwillingness on the part of the major political parties to confront the Supreme Court on the issue of parliamentary prerogatives over constitutional matters means that Ireland is condemned to holding referendums within a political space dominated by both 
nationalist populism and increasing scepticism about the European project. The failure of the Lisbon referendum in Ireland thus dramatically and decisively confirmed the paradigmatic change in Ireland's relationship with the European Union announced by the No to Nice vote in 2001. At the same time it presented the European Union with the latest and perhaps most potent challenge to its ability to achieve a balanced and settled European constitutional order against a backdrop of global economic retrenchment and geopolitical uncertainty. And whilst the Irish Government secured important concessions from the EU at the Brussels European Council summit in December 2008, designed to help it conduct a second referendum in autumn 2009, all the indications are that the outcome of such a second referendum is extremely difficult to predict.

\footnotetext{
${ }^{1}$ I wish to thank the anonymous referees for their advice and directions. I also wish to thank the following for their comments on earlier versions of this paper: Joseph Burke, Patricia Conlan, Katy Hayward, Francis Jacobs, Peadar Kirby, Mary C. Murphy, Sean Ó’Riain, Brid Quinn, and Dolores Taaffe.

${ }^{2}$ See J. O’Brennan, 'Ireland's Return to 'Normal' EU Voting Patterns: The 2002 Nice Treaty Referendum', European Political Science, 2: 2, Spring 2003, pp.5-14; K. Hayward, 'If at First you don't Succeed....': the Second Referendum on the Treaty of Nice, 2002', Irish Political Studies, 18 (1), pp.120-32.

${ }^{3}$ European Commission, 'Post-referendum survey in Ireland', Flash Eurobarometer 245, 18 June 2008; Millward Brown IMS, 'Post Lisbon Treaty Referendum Research Findings', September 2008. The latter body of research was commissioned by the Irish Government in the wake of the failure of the 12 June referendum. In addition to a national poll of more than 2,000 voters it also included the findings from a series of focus groups held in July and August 2008.

${ }^{4}$ This was in stark contrast to the ratification strategies pursued by member states for the Constitutional Treaty (CT) when at least ten member states planned to ratify the Constitution by referendum rather than statute. The French and Dutch rejections of the CT however put paid to the other planned referendums including Ireland's.

${ }^{5}$ On the significance of the Crotty Judgment see J. Temple Lang, The Irish Court Case which delayed the Single European Act (1987) 24 CMLRev 709-18.

${ }^{6}$ R. Fanning, 'Lisbon vote is not democracy but an exercise in buck-passing', The Irish Times, 22 April 2008.

${ }^{7}$ R. Barrington, 'Was holding referendum on Lisbon Treaty really necessary? The Irish Times, 11 July 2008.
} 
${ }^{8}$ G. Barrett, 'Lisbon vote is not buck-passing by politicians', The Irish Times, 24 April 2008.

${ }^{9}$ M. Holmes, 'Opposition to European Integration in Ireland', in M. Holmes (Ed.), Ireland and the European Union Post-Nice, Manchester, Manchester University Press, 2005. See also B. Laffan and J. O'Mahony, 'Managing Europe', in B. Laffan and J. O'Mahony, Ireland and the European Union, Basingstoke, Palgrave, 2008, pp.56-80.

${ }^{10}$ In the 2007 General Election in the Republic Fianna Fáil emerged with the largest number of seats in the Dáil with 77 seats ( $41.6 \%$ of the vote), a loss of 4 from the 2002 election. Fine Gael won 51 seats (27.3\% of the vote), an increase of 20 seats, and Labour won 20 seats (10.1\% of the vote), unchanged from 2002. The Progressive Democrats were decimated at the polls winning just 2 seats ( $2.7 \%$ of the vote) for a loss of 6 seats from 2002.

${ }^{11}$ M. Holmes, op.cit.

${ }^{12}$ Ibid.

${ }^{13}$ See J. O’Brennan, op.cit., note 2.

${ }^{14}$ P. MacLochlainn, 'Does Lisbon Treaty Enhance Democracy? No', The Irish Times, 4 June 2008.

${ }^{15}$ See European Council, Presidency Conclusions, Doc. 17271/08, Brussels, 12 December 2008, note I.2

${ }^{16}$ B. Laffan, 'Astute Irish diplomats are expert at playing the EU system', The Irish Times, 29 May 2008.

${ }^{17}$ See B. Laffan and J. O’Mahony, 'Irish Foreign Policy in the EU', in B. Laffan and J. O’Mahony, Ireland and the European Union, op.cit., pp.175-96; N. Rees, 'Europe and Ireland's Changing Security Policy', in M. Holmes (Ed.), Ireland and the European Union: Nice, Enlargement and the Future of Europe, op.cit., note 9, pp.55-74; B. Tonra, Global Citizen and European Republic: Irish Foreign Policy in Transition, Manchester, Manchester University Press, 2006.

${ }^{18}$ See the three article series by Karen Devine: 'Neither Friend nor Foe: the Irish Position', The Irish Times, 25 November 2008; 'Tug of War between Public and Political Elites', The Irish Times, 26 November 2008 and 'Protecting Neutrality in a Militarised EU', The Irish Times, 27 November 2008. Devine's interpretation of the nature of EU foreign and security policy attracted fierce criticism from a number of scholars. See, notably, P. Keatinge, P. O’Broin and B. Tonra, 'Lisbon will not Override Irish Defence Policy', The Irish Times, 6 December 2008. See also Karen Devine's response to her critics: 'Lisbon 'alliance' is a Step Too Far', The Irish Times, 24 December 2008.

${ }^{19}$ R.Cole, 'If you want to support the arms trade vote Yes', The Irish Times, 17 May 2008.

${ }^{20}$ Millward Brown IMS, op.cit., p.15.

21 'Ganley says tax issue is central to Libertas campaign', The Irish Times, 3 June 2008; D. Ganley, 'Is the Lisbon Treaty good for business? No', The Irish Times, 6 June 2008.

${ }^{22}$ The Irish economy contracted by $1.5 \%$ in the first quarter of 2008 and by up to $2.5 \%$ over the entire year. Other indicators of the depth of the Irish recession can also be cited: in 2008 Ireland experienced the largest ever budget deficit in the history of the state and the single largest shortfall in tax revenue. Unemployment increased to $8 \%$ by the end of 2008, up from $4.5 \%$ at the end of 2007. See:

'Government Records Largest Ever Deficit', The Irish Times, 5 January 2009.

${ }^{23}$ R.Cole, op.cit.

${ }^{24}$ See The Irish Times, 6 June 2008.

25 'Treaty rejected by 110,000 votes in poll of over 1.6 million people', The Irish Times, 14 June 2008.

${ }^{26}$ European Commission, 'Post-referendum Survey in Ireland', Flash Eurobarometer 245, 18 June 2008.

${ }^{27}$ G. Ivaldi, 'Beyond France's 2005 Referendum on the European Constitutional Treaty: Second-Order Models, Anti-Establishment Attitudes and the End of the Alternative European Utopia', West European Politics, Volume 29, Number 1, p.59.

${ }^{28}$ Millward Brown IMS, op.cit., p.1.

${ }^{29}$ R. Sinnott, 'Voters' confidence in their knowledge of treaty is crucial', The Irish Times, 20 May 2008.

${ }^{30}$ Eurobarometer 245, op.cit., p.

${ }^{31}$ R.Sinnott, 'Deeper look at poll illuminates complex reasons for result', The Irish Times, 14 June 2008.

${ }^{32}$ Eurobarometer, op.cit., p.6; Millward Brown IMS, op.cit., p.1.

${ }^{33}$ G. Ivaldi, op.cit., p. 61.

${ }^{34} \mathrm{R}$. Sinnott, op.cit. note 19.

${ }^{35}$ Eurobarometer 245, op.cit., p.6.

${ }^{36}$ R. Sinnott, op.cit. note 21 
${ }^{37}$ J. Coakley, 'Irish public opinion and the new Europe', in M. Holmes (Ed.), Ireland and the Europea Union Post-Nice, Manchester: Manchester University Press, 2005, p.107.

${ }^{38}$ R. Sinnott, op.cit. note 21.

${ }^{39}$ Ireland has received net receipts of approximately $€ 40$ billion since 1973h. In 2007 Ireland received a net amount of $€ 500$ million from the EU budget. The expectation is that Ireland will become a net contributor to the EU budget by 2012. See 'Ireland to contribute $€ 500 \mathrm{~m}$ per year to EU by 2013', The Irish Times, 22 February 2008.

${ }^{40}$ Eurobarometer 245, op.cit., p.3.

${ }^{41}$ Millward Brown IMS, op.cit., p.2.

${ }^{42}$ Ibid., p.8.

${ }^{43}$ See 'Loyalty to party did not sway voters to back treaty', The Irish Times, 26 June 2008.

${ }^{44}$ G. Ivaldi, op.cit., p.52.

${ }^{45}$ Quoted in The Irish Times, 19 May 2008.

${ }^{46}$ Quoted in 'Cowen says he was not sniping at Labour, FG', The Irish Times, 27 May 2008.

${ }^{47}$ Autumn 2008 saw the publication of a number of reports on Ireland's relationship with the European Union and recommendations as to how to move the Lisbon Treaty process forward. See, for example: G. Barrett, B. Laffan, R. Thom, and B. Tonra, 'Ireland's future in Europe: Scenarios and Implications', Report Commissioned by the Oireachtas Sub-Committee on Ireland's Future in the European Union', UCD Dublin European Institute, 12 November 2008; J. O’ Brennan, 'Ireland and the Lisbon Treaty: Quo Vadis? CEPS Policy Brief No.176, October 2008, Centre for European Policy Studies, Brussels, http://shop.ceps.eu/BookDetail.php?item id=1741 ; Oireachtas Sub-Committee on Ireland's Future in the European Union, 'Ireland's Future in the European Union: Challenges, Issues and Options', Houses of the Oireachtas, Dublin, 27 November 2008, http://euaffairs.ie/sub-committee/SubCommitteeReport.pdf

${ }^{48}$ The European Commission has recently produced a report documenting how the Irish media has become more Eurosceptic and tabloid in recent years. The 'changing media landscape' between 2002 and 2008 is identified as an important determinant of changes in public opinion which influenced the Lisbon referendum. See 'Irish media more Eurosceptic, warns EC report', The Irish Times, 2 September 2008.

${ }^{49}$ See J. O’Brennan, 'Ireland's National Forum on Europe: Elite Deliberation meets Popular Participation', Journal of European Integration, Volume 26, Number 2, 2004, pp.167-182; J. O’Brennan, 'The National Forum on Europe', in M. Holmes (ed.) Ireland and the European Union Post-Nice, Op.cit., pp.114-132 